\title{
Study on Ideological Education of College Students under the New Media Environment
}

\author{
Qiuting $L u^{1, a}$ \\ ${ }^{1}$ Student Department, Jilin Agricultural University, Changchun, 130118 \\ ${ }^{a}$ email
}

Keywords: New Media; Ideological and Political Work; Higher Education; Countermeasure

\begin{abstract}
Under the new media environment of ideological and political work is facing a double reality, on the one hand, the extensive use of new media to make objective environment ideological and political work is more complex and diverse body of work, objects, methods, and so are subject to different degrees of impact, the value of college students cognition, lifestyle, learning environment, have also been some impact; the other hand, new media technology in information distribution, information dissemination, and other innovations in the form of information, ideological and political work of college students relying on the new media to carry out ideological education, quality training and so create more favorable conditions. The new concept of the media start of college ideological and political work of college students in the rapid development of the new media environment analysis research, give full play to the positive effects of new media, to avoid adverse effects, combined with actual work proposed to strengthen the ideological and political work of the suggestions.
\end{abstract}

\section{Introduction}

With the development of new media technologies, new media has become an important factor in ideological and political work is seen as the ideological and political workers "double-edged sword." According to China Internet Network Information Center data show: "As of December 2015, Chinese netizens reached 688 million, Internet penetration rate of 50.3\%, more than the global average of 3.9 percentage points, more than the Asian average of 10.1 percentage points among mobile phone users. scale up to 620 million, while the proportion of the student population as high as $46.4 \%$. [1] data from the report show can be seen, the new media create a new social environment, subtle changing mobile Internet users, especially University students everyday life.

In the burgeoning new media study on college students, a great impact on life and the way of thinking at the same time, how will the new things into the concept of higher education, make full use of new media to bring unparalleled convenience, and actively play the new media information propagation characteristics become important elements to be studied and practice. That is, the new media have greater impact on the relationship between higher education and the student body between the widespread use of new media and inspired a wealth of innovation effect of ideological and political education workers to ways and means, With college students in the new media actively guide their value choice, the direction of thinking, and here we are no longer educated to accept the role of unilateral indoctrination, but rather have more space to take the initiative.

\section{The Concept and Characteristics of New Media}

And new media is a relatively broad concept is built on Internet technology and digital media in the form of extensions. First proposed the concept of new media can be traced back 50 years ago, the American Gold Mark in a plan for the development of EVR goods he produced his book, was printed as the main body relative to traditional media for comparison, after popular worldwide use. UNESCO will new media is defined as: "a number of technology-based, network as the carrier medium of information dissemination." In the domestic scholars generally believed that the new media is a variety of applications with respect to the media or traditional media relatively under 
forms, including Internet media, handheld media, new media art, interactive digital media, etc., in terms of social and information dissemination rise WeChat and other new media, enough to reflect its new features. [2] In addition, the new media also highlight the dissemination of information to meet the real-time interaction, communication and entertainment needs; actively cater to people's leisure time fragmentation of demand; select and use content interoperability initiative demand characteristics.

Ideological and political work of the new media environment, is concerned that in the external dissemination of environmental change scenarios on how to develop and innovative ideas ideological and political work, content, ways, is the ideological and political work in full and profound System and Analysis the process of improvement. College students are the most widely used new media people, more and more new media penetration among college students to live and study, and web search also evolved an important way for college students to get information, so the new media in ideological and political work results can not be ignored, however, the development of things from both sides need to look at the analysis, when applied to the new media in ideological and political work, its negative impact is also a need to improve and perfect the exploration work in.

\section{The New Media Environment on College Students' Growth Brings A Positive Role}

Mao Zedong once said: "Our nation, has always been to accept foreign advanced experience and excellent culture of our nation, never refused to accept the fine traditions of other nations.." [3] From ancient times, the Chinese people in "Three under the people's Bank must be my teacher, "the influence of traditional culture, neighborhoods will learn from the virtues of the future generations to continue this work in higher education workers and university students in the new media environment integration process was especially evident. Currently, the new media increasingly deep and broad impact on college students' school life, interpersonal relationships, and other aspects of cognitive value, the ideological, behavioral, psychological and so on in undergoing profound changes, and we can see in the educational process the new media is bringing a lot of positive impact on students' growth.

With the development of new media in particular are increasingly powerful network function, college students study life richer and more convenient. Multimedia, video and other remote teaching methods highly respected in the face of questions, problems, most students will be the first choice for internet search responses, and therefore there has been popular for many years in question to find the "degree mother" argument. College Students study life in the new media environment has become more prevalent in full, in the form of new, versatile new media gradually become a part of campus culture, college campus almost everybody has a cell phone, not only because of the phone consumption levels bonded Students spending power, by phone hidden customize the characteristics of various types of software, terminal, a silent mode of communication is also more in line with the psychological characteristics of college students, new media in learning to the students but also bring convenience to them adds to the fun of life, for life, positive energy excited college students have a certain role in promoting.

He entered the university campus, students interpersonal have more autonomy, and new media widely used largely extended communication range of college students, extending their communicative space. New media greatly shortened the distance between people, make communication more convenient and pluralism in the new media environment, college students can independently establish the exchange of rings, can be no borders and ethnic intangible establish emotional transmission ties, in accordance with their personality and personal preferences flexibility to establish a fresh, personalized interpersonal world, at the same time, in the new media to build interpersonal platform can maximize the sharing of resources, college students not only through more Get channels we need resources, but also more convenient to achieve the exchange of resources. On interpersonal communication state, the use of new media platforms to achieve the simultaneous interaction of all parties, freedom of thought transfer, experience sharing, exchange of experiences demonstrate incomparable superiority, giving college students to create more opportunities for social growth . 
New media development, in particular the prevalence of network break the geographical constraints, so that students understand the world around news, science and technology culture, customs and other needs greater satisfaction. Construction of the new media information channel, the Students 'Experiment with different languages and cultures, ideas, customs, etc., enrich the inner world, and enhance the cultural sentiment, spurred College Students' Growth initiative. No can not be set, new media attention to the affairs of state university students to participate in social life opens a window of the dream, at the same time, traditional media, newspapers, radio, television, etc. are also integrated into the "Internet + " in the process to bring college students international audio-visual experience, a variety of media in their own development and gradually international standards but also to make college students more open international perspective, making them psychologically and are eager to learn the vision to portray itself as more international norm high-quality personnel.

\section{The Adverse Impact of the New Media Environment on Ideological and Political Work}

Information dissemination of new media environment increasingly diverse, to bring a more rapid, more solid, more integrated fresh feeling, we must recognize that the new media with its powerful influence is changing the way people live, especially prominent personality, progressive thinking of the young student population. We can say that the new media give both ideological and political work provides a rare opportunity, but also the development of the ideological and political education work into new media challenges and difficulties faced by prominent.

Information positive concept of the new media environment to promote the dissemination of mainstream thinking healthy development of students, to stimulate their positive energy, strengthen their sense of hard work ahead, but the information obtained is often accompanied by broadening channels of real to the enemy Ideological consciousness of the impact of surging surrounded by leisure and entertainment also subtle influence their real life, and surreal experience of the virtual space are virtually lead to college students and campus life's out of touch. When new media applications contrary to the objectives and principles of higher education, then to carry out ideological and political work is very negative, and the negative effects of the environmental impact of new media, often resulting in the dominant position of ideological and political education workers It tends to fade, resulting in a weakening of the effect of ideological and political education, potentially increasing the difficulty of the ideological and political work.

The current campus culture with a distinct new media era of multicultural characteristics, wide dissemination of new media fast, diversity, its cultural elements of social, recreational, social and other aspects of campus culture really helps enrich the contents, but all-pervasive the media information network public opinion, depression decadent interactive online games, novelty divergent electronic technology to attract the like greatly impact the campus culture status among traditional people physically and mentally dependent on delivery. Campus Culture in ideological and political work in the obvious, different campus culture to cultivate and nurture young talent has a unique cultural charm and ethos, college students not only help the campus culture heritage, but also the construction of the campus culture of force, when they face a series of adverse impact of the new media environment arising from the impact of gradually changing the shape of the new campus life time, but also the process of campus culture set up a wall of obstruction forward pace walls.

The development of new media technology to promote college students' way of thinking has changed dramatically, the direction of higher education will also cultivate new talent and new media technology direction of transformation to adapt it for the college education of the "Times" made higher demands, the ideological and political workers also faces enormous challenges. Network borderless space concept of completely breaking the university campus, university teachers and even school Language can also be very convenient with the outside world ideological confrontation and collision. In the new media conditions conducive to the spread level digestion undermine the authority of "opinion leaders". Specific to the university campus, reflecting the weakening of the authority of the various aspects of knowledge, academic and administrative. [4] some of the 
ideological and political workers in possession of information technology level is not high, not good use of new media resources to carry out education, contemporary and targeted education is obviously not strong; some colleges and universities to carry out ideological and political work in light of the new media the content and form of relatively simple, fusion and forward-looking education have yet to upgrade; in the new media environment, the joint effect of school education, social, family tripartite enough to play, etc., which require ideological and political workers in colleges and universities in practice the process of continuous research and innovation.

\section{Strengthening the New Media Environment, Ideological and Political Work Suggestions}

Under the new media environment, ideological and political workers must pay more attention to a profound impact on the ideological and moral behavior, thinking, lifestyle and other new media environment, pay attention to the important function of the new media in the Ideological Education of College Students Lide tree people during to explore and create a more diverse media support education, the flexibility to choose different carriers based on the actual situation of the students, so that students loved, to enhance ideological and political work interesting, penetration and appeal.

Do a good job of ideological and political work of higher education is a strategic project, consolidate engineering and casting the soul works in the new media environment, ideological and political workers need to be more concerned about the new media environment of ideological and moral behavior, interest in life, etc. profound impact, combined with the new media, in-depth ideological education is essential, as it helps students to more clearly target and motivation ahead of more rational treatment guided by public opinion views the moral direction, smarter Discrimination complex stream of consciousness thoughts of authenticity. Therefore, two classroom ideological and political theory courses and student educational practice second class-based positions, and actively carry out ideological and political work, adhere to healthy positive energy thought to lead; by expanding ideological education, cultural education, practice education people, integrity education, legal education, example education, service education, management education eight channels, relying on network education position open up new ways of ideological and political work, to join fusion of ideology, knowledge, interest, service four in one of the educational content, so that in the new media environment Thoughts on College Students play a positive effect leading to university education characteristics and advantages of the ideals and faith to cultivate high-quality personnel.

"Learning to Live", a book has been written: "If any educational system is only the negative attitude of people and services, if any reform can not cause the learner to actively participate in the activities personally, then this can only be achieved at best minimal education success. "the power of the new media is that it can fully mobilize the enthusiasm of students to actively participate in, the combination of campus culture and new media is bringing new opportunities for personnel training colleges and universities. Current university campus culture flourishing, colorful, schools adhere to promote the theme, highlighting the high-grade, promote diversification, enhance the attractiveness of campus cultural activities in the new media environment, relying on the new media platform to build rich, healthy campus culture brand activities, rich cultural activities at the same time set up the exchange of ideas students, interpersonal communication, the ability to enhance the information network platform, pay attention to the important role of media information network, innovative approaches, seek practical results. Cultural Festival organized by the campus, scientific and cultural festival, community cultural festival, cultural festival bedroom, study and other classic month "five sections of January" activities, to respect the law of education, innovation and education, focusing on the effectiveness of education, deepen the impact of education, ideological and political Students targeted and effective education, to stimulate student motivation and talent of consciousness, but also help foster morality deep roots, highlighting strengths ability, excellent comprehensive quality and ability to realize the young students of color in many aspects of life.

Information is transmitted to the educated educator, is the starting point to carry out ideological and political work, from the point of view of communication, new media for the dissemination of knowledge and values education ideological and political work to create favorable conditions, therefore, actively create a learning team and improve ideological and political work is the key to 
the overall quality of the team. Targeted binding under the New Situation media conducting educational work in special training - carry out ideological and political work of theoretical study team discussions and exchange activities; regularly organized ideological and political work team to enhance the quality of training; strengthening various types of professional training team, especially for newly recruited staff accordingly pre-service training; actively organize and participate in vocational skills competition counselors, teachers lecture competition, etc., to form a "training" to promote learning, to "match" with the school to establish three training two race learning patterns, learning theory, strengthen the capacity of many aspects of training, skills competitions, research work, such as full-service application construction team, to make ideological and political workers in the rich information resources to obtain a more accurate value of having a teaching education educational resources, and the use of combined work to enrich and enhance educators educated with respect to authority.

School plays in the ideological and political work irreplaceable leading role in the social practice of ideological and political education of college students plays a subtle role in guiding the family in the process of growth and success in college students is unparalleled played a role in the wizard, the new media forming environment school, society and family this tripartite educational force ideological and political work, to school education body, community education relying on family education based collaborative mode of education, and give full play to the broad participation of the new media, equality interaction is in line with the development requirements of the times. According to the actual establishment of the new media information technology platform, "School Students - Family - Student - Society - Student - school" chain interaction, and pay attention to the initiative of students' self education, such conduct in the new media environment, ideological and political work is much more three-dimensional, technology: schools can use the wealth of information to provide educational content more selective; Students get more information in the new social media and dealt with while also upgrading their rational thinking; each interaction between the type of network information platform, but also to give more parents understand the student, the student's education space, changing the traditional pattern of home-school education for schools, community, family and the power of new media Three educational combining integrated education people can effectively enhance the effectiveness of ideological and political education work.

\section{References}

[1] China Internet Network Information Center: "37th Statistical Report on Internet Development in China"[EB/OL].http: //www. cnnic. net. cn/ hlwfzyj/ hlwxzbg/ 201601/ P020160122469130059846. Pdf, 2016- 01-22.

[2] Chen Yongdong. Displaying Harbor is to the micro-channel microblogging: are complementary rather than alternative [J]. News and Writing, 2013 (04).

[3] Mao Zedong. Collected Works of Mao Zedong (Vol. 6) [M]. Beijing: People's Publishing House, 1999.

[4] Zhang Zhubo. Opportunities Campus Culture Construction under the new media environment facing Zhang Zhu Bo., Challenges and countermeasures [J]. Beijing Normal University (Social Science Edition), 2013 (01).

[5] Li Linying. Guo Liping Flora Patterns ideological and political education research [M]. in the new media environment. Beijing: People's Publishing House, 2015. 